\section{PENGARUH JUMLAH UANG YANG BEREDAR, TINGKAT BUNGA, \\ NILAI TUKAR RUPIAH, DAN PENDAPATAN NASIONAL}

TERHADAP INFLASI DI INDONESIA

\section{Oleh: Ali Muhson}

\section{ABSTRAK}

Inflasi merupakan gejala ekonomi yang keberadaannya diperlukan untuk mendukung pertumbuhan ekonomi Indonesia. Sebaliknya jika inflasi tidak dapat dikendalikan secara baik dapat berdampak pada merosotnya perekonomian bangsa. Untuk itu kebijakan pengendalian inflasi perlu dilakukan secara tepat. Berkaitan dengan permasalahan tersebut penelitian ini bertujuan untuk mengetahui (1) pengaruh jumlah uang yang beredar mempunyai terhadap inflasi, (2) pengaruh nilai tukar rupiah terhadap inflasi, (3) pengaruh tingkat bunga terhadap inflasi, dan (4) pengaruh pendapatan nasional terhadap inflasi.

Penelitian ini merupakan penelitian ex post facto yang pengumpulan datanya dilakukan dengan teknik dokumentasi. Periode data yang diambil antara tahun 1980 sampai dengan 1999. Data tersebut diperoleh dari Laporan Tahun Bank Indonesia dalam terbitan beberapa tahun. Teknik analisis yang digunakan adalah analisis regresi yang menggunakan model yang dikembangkan oleh Cobb Dauglas.

Hasil penelitian ini menemukan bahwa dengan analisisi regresi metode enter ditemikan bahwa secara bersama-sama terdapat huỏungan yang signifinan antura jumluh uang yang beredar, tinghat bunga. nilai tukar rupiah, $P D B$, dan tingkat inflasi. Kontribusi bersamanya sebesar $74 \%$ dengan harga $F$ sebesar 9,942 dan $p<0,05$. Namun demikian secara sendiri-sendiri (parsial) yang memiliki kontribusi yang signifikan terhadap tingkat inflasi hanyalah variabel $P D B(t=3,206 ; p<0,05)$, sedangkan variabel lainnya tidak memilik kontribusi parsial yang signifikan. Model regresi tersebut juga sudah memenuhi asumsi klasik, yang meliputi asumsi normalitas, homosedastisitas, multikolinearitas, dan otokorelasi. Berdasarkan hasi analisis regresi dengan metode stepwise ditemukan bahwa variabel yang secara nyata berkontribusi terhadap tingkat inflasi adalah PDB $(t=3,861 ; p<0,05)$ dan nilai tukar rupiah $(t=2,324 ; p<0,05)$, sedangkan variabel lainnya tidak memiliki kontribusi yang signifikan. Variabel yang paling besar kontribusinya adalah variabel $P D B$ dengan

kontribusi sebesar 62,9\%, sedangkan kontribusi tambahan yang dihasilkan oleh variabel nilai tukar rupiah adalah sebesar 9,4\%. Dengan demikian, secara bersama-sama kedua variabel tersebut memiliki kontribusi sebesar $72,3 \%$ dengan harga $F=20,854$ dan $p<0,05$. Untuk model regresi yang ditemukan ini juga telah memenuhi persyaratan asumsi klasik yang meliputi asumsi normalitas, homosedastisitas, multikolinearitas, dan otokorelasi.

Kata kunci: Inflasi, jumlah uang yang beredar, tingkat bunga, nilai tukar rupiah, dan pendapatan nasional

\section{A. Pendahuluan}

Sejak pertengahan tahun 1997. perekonomian Indonesia mengalami krisis ekonomi yang berkepanjangan. Sampai sekarang pun tanda-tanda berakhirnya krisis ekonomi itu belum tampak, sehingga mengakibatkan Indonesia semakin terpuruk Seiring dengan terjadinya krisis yang berkepanjangan tersebut, larpa barang dan jasa pun semakin meningkat tajam. Kebijaksanaan pemerintah untuk menaikkan harga Dahan Bakar Minyak (BBM) dan tarif dasar listrik pun bcrakibat mendongkrak harga barang menjadi. lebih tinggi lagi. Jika hal ini dibiarkan maka beban rakyai yang sudah berat akibat adanya krisis ini menjadi acmakin berat karena pendapatan riil masyarakat menjadi semakin rendah akibat adunya kenaikan harga-harga barang kebutuhan pokok dan barangbarang lainnya. Jika hal ini dibiarkan maka akan berakibat semakin meningkatnya angka kemiskinan dan pada akhirnya akan berdampak pada aspek-aspek kehidupan yang lain seperti meningkatnya kriminalitas dan menurunnya kepercayaan masyarakat terhadap pemerintah.

$$
\text { Di masa Orde Baru, laju }
$$

inflasi selalu dijadikan sebagai indikator keberhasilan dalam pembangunan perekonomian Indonesia. Pemerintah selalu mengambil kebijaksanaan untuk menekan laju pertumbuhan inflasi, bahkan pemerintah selalu menargetkan bahwa laju inflasi harus di bawah dua digit. Hal ini dilakukan agar beban masyarakat tidak semakin berat akibat adanya kenaikan harga tersebut. Oleh karena itu hampir di

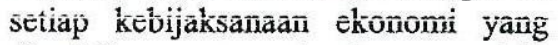
diambil pemerintah selalu mempertimbangkan dampaknya terhadap kenaikan harga barang dan jasa.

Setiap negara, baik negara maju maupun negara yang sedang berkembang, sudah dapat dipastikan bahwa perekonomiannya akan selalu 
mengalami inflasi, hanya saja besarnya berbeda. Menurut Sudarso (1993), biasanya negara-negara yang sudah maju tingkat inflasinya relatif lebih kecil dibandingkan dengan negara-negara yang sedang berkembang. Laju inflasi di negaranegara maju di tahun 1982 rata-rata sckitar 7\%, namun dewasa ini lebih rendah dari $3 \%$. Bahkan pada tahun 1989, Jerman Barat dan Jepang masing-masing hanya mengalami laju inflasi sebesar $1,8 \%$ dan $0,9 \%$. Di tahun yang sama tersebut laju inflasi Indonesia mencapai $6,5 \%$, namun di tahun berikutnya laju inflasi di Indonesia mencapai $12,4 \%$. Keadaan tersebut menunjukkan bahwa di negara-negara maju telah mampu mengendalikan laju inflasi.

Adanya inflasi di satu sisi dapat dianggap sebagai pemicu pcrtumbuhan perekonomian, namun di sisi lain, jika inflasi tersebut tidak dapat dikendalikan secara baik akân berdampak pada lumpuhnya perekonomian negara. Indonesia pernah mengalami laju inflasi yang tidak terkendali di tahun 1960-an dan sudah merasakan dampak negatifnya. Oleh karena itu sudah selayaknya kalau laju inflasi di Indonesia harus mampu dikendalikan secara baik agar beban hidup rakyat tidak semakin berat.

Perekonomian Indonesia memang sangat memerlukan laju inflasi yang rendah karena inflasi yang rendah mencerminkan stabilitas harga.
Secara makro, stabilitas harga memberikan garansi dan sekaligus merupakan representasi bagi stabilitas ekonomi, terutama dalam memberikan iklim yang kondusif bagi investor, baik lokal maupun investor asing, yang saat ini sangat dibutuhkan dalam rangka pemulihan perekonomian Indonesia. Stabilitas ekonomi juga akan mampu meningkatkan daya saing ekspor dan produksi dalam negeri terhadap membanjirnya barang-barang impor.

Dari sudut pandang mikro, inflasi yang rendah juga memberikan kepastian dan rasa aman bagi keputusan portofolio dan pemegang uang tunai. Inflasi yang tinggi praktis menggerogoti nilai mata uang sehingga orang cenderung lebih sedikit memegang uang tunai karena menurunkan kepercayaan masyarakat terhadap nilai uang sehingga menekan tabungan dan investasi: Jika hal ini terjadi akan berakibat terhambatnya pertumbuhan ekonomi karena investasi berkurang.

Pada umumnya inflasi mencakup tiga aspek, yaitu:

1. Adanya kecenderungan hargaharga untuk meningkat, yang berarti mungkin saja tingkat harga yang terjadi pada waktu tertentu turun atau naik dibandingkan dengan sebelumnya, tetapi tetap menunjukkan kecenderungan yang meningkat.

2. Peningkatan harga tersebut berlangsung terus-menerus (sustained)' yang berarti bukan terjadi pada satu waktu saja.

3. Mencakup pengertian tingkat larga umum (general level of price), yang berarti tingkat harga yang meningkat itu bukan hanya pada satu atau beberapa komodit saja, melainkan kenaikan tersebut hampir dialami oleh semua komoditi yang ada.

$$
\text { Menurut Bidiono (1982) }
$$

berdasarkan asal usulnya inflasi terbagi atas:

1. Domestic Inflation, yaitu inflasi yang berasal dari dalam negeri Inflasi ini dapat terjadi karena defisit anggarap pemerintah yang dibiayai dengan mencetak uang baru, panen yang gagal meningkaunya permintaan efekti dari masyarakat di atas kenaikan penawaran, dan meningkatnya biaya produksi barang-barang dalam negeri sehingga mengakibatkan naiknya harga jual, dan sebagainya.

2. Imported Inflation, yaitu inflasi yang berasal dari luar negeri. Inflasi ini dapat terjadi karena. adanya sistem perekonomian yang terubika. Semakinin besaĩ ketergantungan perekonomian pada perdagangan dan keuangan internasional akan semakin besar efck inflasi luar negeri terbadap inflasi dalam negeri.

Berdasarkan sebab awalnya, Lipscy dan Steiner (1981) mencoba membagi inflasi ke dalam tiga bagian, yaitu:

1. Demand-pull theories of inflation. Menurut teori ini inflasi disebabkan oleh faktor-faktor yang menggeser aggregate demand sehingga tercipta keadaan excess demand yang merupakan inflationary gap akibatnya menekan harga untuk naik. Peningkatan aggregate demand pada keadaan full employment akan menyebabkan terjadinya kelebihan permintaan pada pasar barang dan jasa sehingga harga barang dan jasa meningkat. Sementara itu, peningkatan permintaan terhadap barang dan jasa tersebut akan menyebabkan terjadinya peningkatan harga faktor produksi. Kenaikan harga barang dan jạsa dan kenaikan harga faktor produksi ini merupakan inflasi daiam perekonomian.

2. Supply-side theories of inflation. Teori ini menekankan: pada terjadinya pergesran kurva aggregate supply sebagai penyebab utama inflasi. Pcininghatanin kưva agaregate supply tersebut menyebabkan bergesernya keadaan ekuilibrium dalam keadaan harga yang lebih tinggi dan output yang lebih rendah.

3. Demand-supply theories of inflation. Menurut teori ini adanya peningkatan aggregate 
demand menyebabkan terjadinya kenaikan harga yang kemudian diikuti oleh peningkatan aggregate supply sehingga harga naik lebih tinggi lagi. Kenaikan tersebut terjadi karena adanya harapan bahwa tingkat harga dan upah akan meningkat atau karen adanya kelebaman atau inersia dari inflasi masa lalu.

Menurut Budiono (1982), ada tiga kelompok teori inflasi, yaitu:

1. Teori kuantitas Teori ini menyoroti inflasi dari sisi jumlah uang yang beredar dan psikologi (harapan) masyarakat mengenai kenaikan harga di masa yang akan datang. Menurut teori ini inflasi hanya dapat terjadi kalau ada penambahan jumlah uang yang beredar, baik dalam bentuk uang kartal maupun giral. Di samping itu inflasi juga dapat disebabkan oleh adanya harapan masyarakat mengenai kenaikan harga-harga di masa yang akan datang.

2. Teori Keynes

Teori ini menyatakan bahwa inflasi terjadi karena masyarakat ingin hidup di luar batas kemampuan ekonominya. Inflasi merupakan proses perebutan rezeki di antara kelompok sosial yang menginginkan bagian yang lebih besar dari yang bisa disediakan masyarakat tersebut. Jadi inflasi timbul bila permintaan masyarakat akan barang-barang selalu melebihi jumlah barang yang tersedia. Inflasi akan berhenti bila permintaan efektif total tidak melebihi output yang tersedia pada harga yang berlaku.

3. Teori Strukturalis Teori ini memberikan tekanan pada ketegaran dari struktur perekonomian negaranegara berkembang. Menurut teori ini, ada dua ketegaran dalam perekonomian negara berkembang yang dapat menimbulkan inflasi, yaitu:

a. Ketidakelastisan penerimaan ekspor, artinya nilai ekspor berkembang secara lebih lamban dibandingkan dengan pertumbuhan sektor-sektor lain. Faktor-faktor penyebabnya $\mathrm{di}$ antaranya adalah adanya terms of trade yang makin memburuk sehingga harga ekspor tidak menguntungkan, dan kelambanan pertumbuhan penerimaan ekspor sehingga pemerintah harus mengambil kebijaksanaan untuk menckan produksi dalam negeri atas barang-barang yang sebelumnya diimpor. Bila kebijaksanaan substitusi impor tersebut meluas akan berakibat pada naiknya biaya produksi yang pada akhirnya kenaikan tersebut meluas ke berbagai barang. b. Ketidakelastisan penawaran bahan makanan dalam negeri. Keccpatan pertumbuhan penduduk dan pendapatan per kapita melebihi pertumbuhan produksi bahan makanan akan mengakibatkan kenaikan harga bahan makanan melebihi harga barang-barang lain sehingga menimbulkan tuntutan kenaikan upah dan selanjutnya menaikkan ongkos produksi.

Mengingat

perlunya

pengendalian secara baik terhadap laju nกlasi maka perlu dikaji mengenai faktor-faktor yang mempengaruhi laju inflasi di Indonesia agar dapat diambil kebjaksanaan yang kondusif bagi pengendalian laju inflasi. Untuk itulah penelitian ini berupaya untuk mengkail bebęrapa faktor yang mempengaruhi laju inflasi di Indonesia. Adapun permasalahan yang dikaji adalah bagaimana pengaruh jumlah uang yang beredai, nilai tukai rupiah, tingkat bunga, dan pendapatan nasional terhadap inflasi di Indonesia?

\section{Motode Penelitian}

Penelitian ini termasuk dalam kategori penelitian ex post facto karena dalam mengumpulkan data peneliti tidak berusaha untuk memberikan perlakuan apapun, akan telapi peneliti mengumpulkan data netelah semua kejadian yang dipernoalkan berlangsung (Ary, dkk,
1982). Adapun pendekatan yang dipakai dalam penelitian ini adalah pendekatan kuantatif karena data yang dikumpulkan dari hasil penelitian ini berupa data yang dapat dikuantifikasikan.

Penelitian ini menggunakan data sekunder sehingga teknik pengumpulan data yang digunakan adalah teknik dokumentasi. Dokumen yang dijadikan acuan dalam penelitian ini adalah dokumen yang diperoleh dari "Laporan Tahunan Bank Indonesia" dalam terbitan beberapa tahun. Adapun data yang dikumpulkan dalam penelitian ini meliputi data tentang PDB, Jumlah uang yang beredar, nilai tukar rupiah, tingkat bunga, dan: tingkat inflasi selama kurun waktu 1980 sampai dengan 1999.

Teknik analisis data yang digunakan dalam penelitian ini adalah menggunakan teknik analisis regresi dengan model Ordinary Leasis Square (OLS). Sedangkan model regresi yang digunakan dalam penclitian mengikuti model yang dikembangkan oleh Cobb Douglas, yakni:

$$
\begin{aligned}
& \mathrm{Y}=\mathrm{a} \mathrm{X}_{1}^{\mathrm{b} 1} \mathrm{X}_{2}^{\mathrm{b} 2} \mathrm{X}_{3}{ }^{\mathrm{b} 3} \mathrm{X}_{4}^{\mathrm{b} 4} \\
& \text { Keterangan: } \\
& \mathrm{Y}=\text { Tingkat inflasi } \\
& \mathrm{X}_{1}=\text { Jumlah uang yang } \\
& \text { beredar } \\
& \mathrm{X}_{2}=\text { Tingkat bunga } \\
& \mathrm{X}_{3}=\text { Nilai tukar rupiah } \\
& \mathrm{X}_{4}=\text { Produk Domestik } \\
& \text { Bruto (PDB) }
\end{aligned}
$$




\section{Hasil Penelitian}

Inflasi yang terjadi di Indonesia selama kurun waktu tahun 1980 sampai dengan 1999 berkisar antara 2,01 sampai dengan 77,6 persen. Tingkat inflasi terendah dicapai pada tahun 1999, sedangkan inflasi tertinggi dicapai pada tahun 1998 karena di tahun itulah terjadi puncak krisis ekonomi yang melanda Indonesia sejak pertengahan tahun 1997. Dalam kurun waktu tersebut rata-rata laju inflasi per tahunnya adalah $12,58 \%$, dengan standar deviasi $15,65 \%$.

Pertumbuhan jumlah uang yang beredar di Indonesia selama tahun 1980-1999 juga mengalami peningkatan untuk setiap tahunnya. Jika di tahun 1980 jumlah uang yang beredar sebanyak Rp 4.995,00 milyar, maka di tahun 1999 meningkat menjadi $\mathrm{Rp} 124.633,00$ milyar. Adapun laju pertumbuhan per tahunnya berikisar antara $6,29-39,76$ persen, dengan rata pertumbuhan sebesar $18,75 \%$ dan standar deviasi $8,81 \%$.

Tingkat suku bunga dalam kurun waktu 1980-1999 mengalami nerubahan-nerubahan dengan kisaran $12,53 \%$ sampai dengan $65,67 \%$. Suku bunga terendah tersebut dialami di tahun 1994 sedang tertinggi terjadi pada saat krisis ekonomi di tahun 1998. Walaupun demikian selama kurun waktu tersebut rata-rata tingkat suku bunga per tahun adalah $19,86 \%$ dengan standar deviasi $11,34 \%$
Perkembangan nilai tukar rupiah terhadap dollar Amerika selama kurun waktu 1980-1999 mengalami fluktuasi, terutama akiba adanya krisis ekonomi yang memang berawal dari merosotnya nilai tuka rupiah terhadap dollar Amerika Fluktuasi nilai tukar rupiah terhadap dollar Amerika tersebut berkisa antara 627-10.587,5 rupiah. Adapun laju pertumbuhan nilai tukar rupial tersebut sempat mengalami penurunan sebesar 5,34\% di tahun 1990 dan $17,44 \%$ di tahun 1999, namun kenaikan tertinggi dicapai pada saa krisis ekonomi di tahun 1998 yakn sebesar $125,54 \%$. Selain itu rata-rata laju pertumbuhan nilai tukar rupiah dalam kurun waktu tersebut adalal sebesar $18,68 \%$ dengan standar deviasi $35,8 \%$.

Selama kurun waktu 1980 1999 jumlah PDB Indonesia selalu mengalami kenaikan dari tahun ke tahun. Jumiah PDB di tahun 1980 adalah sebesar 45.446 milyar rupiah, jumlah tersebut di tahun 1999 meningkat menjadi 1.099.731,6 milya rupiah. Adapun laju pertumbuhan PDB di Indonesia dalam kurun wakt 1981-1999 berkisar antara 6.42 - 52,27 persen, sedangkan rata-rata pertumbuhan PDB per tahunnya adalah $18,57 \%$ dengan standar deviasi $9,30 \%$

Untuk menguji apakah ada mobungan antara jumlah uang yang leredar (X1), lingkat suku bumga (X2), nilai tukar rupiah (X3), PDB (Xi1), dan tingkat inflasi(Y) digunakan

esi ganda dengan menggunakan model Cobb Douglas. Hasil analisis regresi tersebut disajikan pada Tabel 6 berikut ini:

Tabel 1

Hasil Analisis Regresi Ganda dengan Metode Enter

\begin{tabular}{|l|r|r|r|r|r|c|}
\hline Variabel & Kocfisien & \multicolumn{1}{c|}{$\mathrm{t}$} & $\mathrm{p}$ & $\mathrm{R}^{2}$ & $\mathrm{~F}$ & $\mathrm{p}$ \\
\hline Konstanta & $-11,772$ & $-2,933$ & 0,011 & 0,740 & 9,942 & 0,001 \\
$\log \mathrm{X1}$ & $-1,195$ & $-0,893$ & 0,387 & & & \\
$\log \mathrm{X} 2$ & $-0,149$ & $-0,328$ & 0,748 & & & \\
$\log \mathrm{X3}$ & 0,982 & 2,048 & 0,060 & & & \\
$\log \mathrm{X} 4$ & 6,453 & 3,206 & 0,006 & & & \\
\hline
\end{tabular}

Berdasarkan hasil analisis di (ain diperoleh besarnya koefisien leierminasi sebesar 0,740 dengan larga I sebesar 9,942 $(\mathrm{p}<0,05)$. Oleh karena $\mathrm{p}$ lebih kecil dari 0,05 maka dapai disimpulkan bahwa ada libbmgan yang signifikan antara imblah uang yang beredar (Xi), ingkat suku bunga (X2), nilai tukar repiah (X3), PDB (X4), dan tingkat inflasi $(\mathrm{X})$. Olch karena besarnya coefisien determinasi adalah 0,740 . berarti total variansi tingkat inflasi yane dapat dijelaskañ olch variabel umlah uang yang beredar, tingkat viku bunga, nilai tukar rupiah, dan 01) adalah sebesar $74 \%$ melalui model regresi yang ditemukan, nedangkan sisanya sebesar $26 \%$ berasal dari variabel lain.

Oleh karena secara bersamaแama terbukti ada hubungan yang signifikan, maka untuk memperoleh model regresi yang tepat perlu diuji apakah secara sendiri-sendiri (parsial) seluruh variabel bebas tersebut juga memiliki kontribusi yang signifikan terhadap variabel terikat. Untuk itu periu dilakukan pengujian terhadap koefisien regresi yang ditemukan.

$$
\text { Berikut ini disajikan }
$$

pengujian terhadap koeñisien :regresi secara parsial:

1. Hasil pengujian terhadap koefisien $b_{1}$ ditemukan nilai $t$ sebesar $-0,893$ dengan $p>0,05$. Oleh karena $\mathrm{p}$ lebih besar dari 0,05 maka disimpulkan bahwa tidak ada hubungan antara jumlah uang yang beredar dan tingkat inflasi jika variabel bebas yang lain dikendalikan 
2. Hasil pengujian terhadap koefisien $b_{2}$ ditemukan nilai $t$ sebesar $-0,328$ dengan $p>0,05$.

Oleh karena p lebih besar dari 0,05 maka disimpulkan bahwa tidak ada hubungan antara tingkat suku bunga dan tingkat inflasi jika variabel bebas yang lain dikendalikan.

3. Hasil pengujian terhadap koefisien $b_{3}$ ditemukan nilai $t$ sebesar 2,048 dengan $p>0,05$.

Oleh karena $\mathrm{p}$ lebih besar dari 0,05 maka disimpulkan bahwa tidak ada hubungan antara nilai tukar rupiah dan tingkat inflasi jika variabel bebas yang lain dikendalikan.

4. Hasil pengujian terhadap koefisien $b_{1}$ ditemukan nilai sebesar 3,206 dengan $p<0,05$. Oleh karena $\mathrm{p}$ lebih kecil dari 0,05 maka disimpulkan bahwa ada hubungan antara produk domestik bruto dan tingkat inflasi jika variabel bebas yang lain dikendalikan. Artinya semakin tinggi PDB semakin tinggi tingkat inflasi walaupun variabel lain dianggap konstan.

Untuk meyakinkan ketenatan model regresi yang digunakan tersebut perlu diuji persyaratan-persyaratan scbagai berikut:

1. Hasil uji normalitas terhadap residu (error) menunjukkan bahwa harga $\mathrm{z}$ KolmogorovSmirnov yang ditemukan adalah sebesar 0,540 dengan $\mathrm{p}>0,05$.
Oleh karena harga $\mathrm{p}$ lebih besar dari 0,05 maka dapat disimpulkan bahwa asunsi klasik tentang kenormalan residu dapat terpenuhi.

2. Hasil uji homosedastisitas dengan model Glesjer ditemukan bahwa harga $\mathrm{F}$ hitung sebesar 0,344 dengan $p>0,05$. Oleh karena harga p lebih besar dari 0,05 maka dapat disimpulkan bahwa model regres yang digunakan terbebas dari adanya heterosedastisitas.

3. Hasil uji muitikolinearitas dengan VIF ditemukan bahwa harga VIFnya berkisar antara 1,149 sampai dengan 2,806. Oleh karena harga VIF tersebut jauh lebih kecil dari 4 maka dapat disimpulkan bahwa tidak terjadi multikolinearitas dalam model regresi.

4. Hasil uji otokorelasi dengan metode Durbin-Watson ditemukan bahwa harga DW hitungnyà sebesar 1,735, sedangkan harga $\mathrm{d}_{\mathrm{L}}=0,65$ dan $\mathrm{d}_{U}$ $=1,58$. Oleh karena harga DW hitung terletak antara $d_{U}$ dan $4-d_{U}$ maka dapat disimpulkan bahwa model regresi tersebut terbebas dari otoknrelasi

\section{Kesimpulan}

Beberapa kesimpulan yang dapat diambil dari hasil penelitian ini adalah sebagai berikut:

1. Dengan analisisi regresi metode enter ditemukan bahwa secara bersama-sama terdapat hubungan yang signifikan antara jumlah uang yang beredar, tingkat bunga, nilai tukar rupiah, PDB, dan tingkat inflasi. Kontribusi bersamanya sebesar $74 \%$ dengan harga $F$ sebesar 9,942 dan $p<0,05$. Namun demikian secara sendirisendiri (parsial) yang memiliki kontribusi yang signifikan terhadap tingkat inflasi hanyalah variabel PDB, sedangkan variabel lainnya tidak memiliki kontribusi parsial yang signifikan. Model regresi tersebut juga sudah memenuhi asumsi klasik, yang meliputi asumsi normalitas, homosedastisitas,

multikolinearitas, dan otokorelasi.

2. Berdasarkan hasil analisis regresi dengan metode stepwise ditemukan bahwa variabel yang secara nyata berkontribusi terhadap tingkat inflasi adalah PDB dan nilai tukar rupiah, sedangkan variabel lainnya tidak berkontribusi. Variabel yang paling besar kontribusinya adalah variabel PDB dengan kontribusi sebesar $62,9 \%$, sedangkan kontribusi tambahan yang dihasilkan oleh variabel nilai tukar rupiah adalah sebesar $9,4 \%$. Dengan demikian, secara bersama-sama kedua variabel tersebut memiliki kontribusi scbesar $72,3 \%$ dengan harga $F=$ 20,854 dan $\mathrm{p}<0,05$. Untuk model regresi yang ditemukan ini juga telah memenuhi persyaratan asumsi klasik yang meliput asumsi normalitas, homosedastisitas, ultikolinearitas, dan otokorelasi.

E. Saran

Berdasarkan hasil temuan in dapat diajukan beberapa saran berikut ini:

1. Dengan ditemukannya bahwa PDB merupakan faktor yang paling besar pengaruhnya terhadap tingkat inflasi maka dapat diajukan saran bahwa untuk melakukan pengendalian inflasi perlu memperhatikan tingkat PDBnya. Hal ini dimaksudkan bahwa jika PDB semakin tinggi maka daya beli masyarakat menjadi tinggi. Jika hal ini tidak diimbangi dengan ketersediaan barang dan jasa yang memada maka dapat mengakibatkan kenaikan harga barang dan jasa.

2. Nilai tukar rupiah juga menjadi faktor penyebab terjadinya inflasi. Untuk itu dalam melakukan pengendalian inflasi perlu diambi kebijakan untuk menstabilkan nilai tukar rupiah terhadap dollar Amerika. Jika nilai tukar rupiah tidak terkendali seperti yang telah terjadi mulai pertengahan tahun 1997 maka akan berakibat tingkat inflasi menjadi tidak dapat dikendalikan.

3. Dengan tidak ditemukannya hubungan antara jumlah uang yang beredar, tingkat bunga, dan 
tingkat inflasi dalam penelitian ini, bukan berarti bahwa kedua variabel tersebut tidak berpengaruh terhadap tingkat inflasi. Tidak terbuktinya hipotesis tersebut dapat terjadi karena hal-hal berikut ini:

a. Periode waktu yang diambil dalam penelitian ini terlalu pendek, yakni hanya 20 tahun sehingga dapat menjadikan hasilnya kurang menggambarkan yang sesungguhnya.

b. Jumlah uang yang beredar yang diukur dalam penelitian ini hanya terbatas pada jumlah uang dalam arti sempit, yakni uang kartal dan uang giral, padahal masih ada uang kuasi yang terdiri atas deposito berjangka dan tabungan, baik dalam bentuk rupiah maupun valuta asing, serta giro valuta asing milik penduduk.

c. Tingkat bunga yang diukur hanya terbatas pada tingkat bunga kredit, tidak memperhitungkan tingkat bunga tabungan, deposite, atau yang lainnya.

Untuk itu bagi peneliti lain yang tertarik dengan topik ini disarankan untuk melakukan penelitian secara lebih komprehensif dalam arti periode waktu dan pengukurannya.

\section{DAFTAR PUSTAKA}

Ari Sudarman dan Algifari (1991). Ekonomi Mikro-Makro Yogyakarta: BPFE

Ary, D, dkk. (1982). Pengantar Penelitian dalam Pendidikan. (Alihbahasa: Arief Furchan) Surabaya: Usaha Nasional.

Boediono (1985). Ekonomi Moneter: Seri Pengantar Ilmu Ekonomi. Yogyakarta: BPFE

Gujarati, Damodar. (1995). Ekonometrika Dasar (Alihbahasa: Sumarno Zein). Jakarta: Airlangga

Lipsey, R.G. and Steiner, P.O. (1981) Economics. Sixth Edition. New York: Harper and Row Publisher

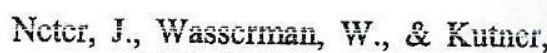
M.H. (1983). Applied Linear Regression Model. Illinois: Richard D. Irwin, Inc.

Pedhazur, E.J. (1982). Multiple Regression in Behavioral Research: Explanation and Prediction. New York: Holt, Rinehart and Winston

Samuelson, P.A. and Nordhaus, W.D. (1986). Ekonomi Jilid I
(Alihbahasa: Jaka Wasana

M.). Jakarta: Erlangga

Hudarso. (1991). Pengantar Ekonomi Makro. Jakarta: Rineka Cipta

Audjana. (1996). teknik Analisis Regresi dan Korelasi Bagi Para Peneliti. Bandung: tarsito

Aupranto, J. (1984). Ekonometrik, Buku Dua. Jakarta: Lembaga Penerbit Fakultas Ekonomi UI 